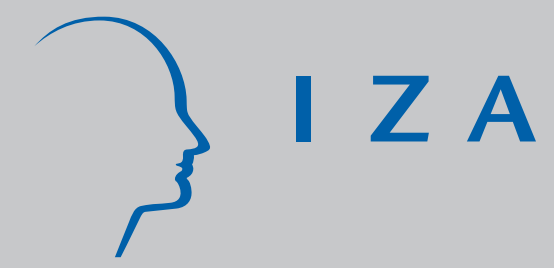

IZA DP No. 624

Personal and Regional Determinants of Entrepreneurial Activities: Empirical Evidence from the REM Germany

J oachim Wagner

Rolf Sternberg

November 2002 


\title{
Personal and Regional Determinants of Entrepreneurial Activities: Empirical Evidence from the REM Germany
}

\author{
Joachim Wagner \\ University of Lueneburg, HWWA and IZA Bonn \\ Rolf Sternberg \\ University of Cologne
}

Discussion Paper No. 624

November 2002

\author{
IZA \\ P.O. Box 7240 \\ D-53072 Bonn \\ Germany \\ Tel.: +49-228-3894-0 \\ Fax: +49-228-3894-210 \\ Email: iza@iza.org
}

This Discussion Paper is issued within the framework of IZA's research area Mobility and Flexibility of Labor. Any opinions expressed here are those of the author(s) and not those of the institute. Research disseminated by IZA may include views on policy, but the institute itself takes no institutional policy positions.

The Institute for the Study of Labor (IZA) in Bonn is a local and virtual international research center and a place of communication between science, politics and business. IZA is an independent, nonprofit limited liability company (Gesellschaft mit beschränkter Haftung) supported by the Deutsche Post AG. The center is associated with the University of Bonn and offers a stimulating research environment through its research networks, research support, and visitors and doctoral programs. IZA engages in (i) original and internationally competitive research in all fields of labor economics, (ii) development of policy concepts, and (iii) dissemination of research results and concepts to the interested public. The current research program deals with (1) mobility and flexibility of labor, (2) internationalization of labor markets, (3) welfare state and labor market, (4) labor markets in transition countries, (5) the future of labor, (6) evaluation of labor market policies and projects and (7) general labor economics.

IZA Discussion Papers often represent preliminary work and are circulated to encourage discussion. Citation of such a paper should account for its provisional character. A revised version may be available on the IZA website (www.iza.org) or directly from the author. 
IZA Discussion Paper No. 624

November 2002

\section{ABSTRACT \\ Personal and Regional Determinants of Entrepreneurial Activities: Empirical Evidence from the REM Germany*}

This paper contributes to empirical research in entrepreneurship by focusing on the link between two stylized facts that emerged from a number of studies for Germany and other countries: Entry rates differ between regions, and the propensity to become an entrepreneur is influenced by socio-demographic variables and attitudes. We develop a theoretical framework to discuss this link, and we test whether for a person of a given age, degree of schooling, attitude towards risk etc. regional variables do matter for the decision to start a new business ceteris paribus. Our econometric study is based on data for 10.000 persons from a recent representative survey of the population in ten German planning regions, the Regional Entrepreneurship Monitor (REM). We use a version of the probit model that takes care of the regional stratification of the data, and the results of the nonlinear models are carefully interpreted and illustrated. We find that the propensity to step into self-employment is, among others, higher for males, unemployed, people with contacts to a role model, and with past entrepreneurial experience, who live in more densely populated and faster growing regions with higher rates of new firm formation, while risk aversion and high prices of land have the opposite impact.

JEL Classification: J23, R12

Keywords: nascent entrepreneurs, Germany, regions

Corresponding author:

Joachim Wagner

University of Lueneburg

Institute of Economics

D-21332 Lueneburg

Germany

Tel.: +494131782330

Fax: +494131782026

Email: wagner@uni-lueneburg.de

\footnotetext{
* Research for this paper was done as part of the project Regional Entrepreneurship Monitor REM Germany financially supported by the German Research Foundation (DFG STE 628/7-1/2 and WA $610 / 2-1 / 2)$.
} 


\section{Motivation}

Although comprehensive data from official statistics on new firm formation and entrepreneurs starting a new business are lacking in Germany, we know from a number of empirical studies that entry rates differ between regions, and that the propensity to become an entrepreneur is influenced by socio-demographic variables and attitudes:

- A comparison of results from several countries (France, Germany, Italy, Sweden, the UK, and the US) by Reynolds, Storey and Westhead (1994) shows that start-up rates vary by a factor of two to four between regions within a country. A large number of empirical studies investigate the determinants of these inter-regional variations in new firm formation. A comprehensive survey can be found in Steil (1999); for Germany, see Audretsch and Fritsch (1994, 2002), Fritsch and Falk (2002), and Gerlach and Wagner (1994). All of these studies on inter-regional variation in new firm formation are based on aggregate data at the level of the region and, therefore, ignore information at the level of the individuals that act as entrepreneurs in the process of market entry.

- According to results from a large number of empirical studies surveyed by Chell, Haworth and Brearly (1991) and Evans and Siegfried (1994) personal characteristics and attitudes have an important impact on the decision to become an entrepreneur. For Germany, this has been documented in recent studies by Frick et al. (1998), Lagemann et al. (1999) and Sternberg (2000). These studies are based on micro data for individuals and, therefore, ignore information measured at the level of the region a person lives in.

The focus of our paper is on the link between these two literatures. In our investigation we take a point of view that differs from the one usually followed in the literature on inter-regional differences in new firm formation. The dependent variable in our empirical models is not the number or rate of start-ups in a region that is regressed on a group of independent variables measuring various characteristics of the region which are expected to be positively or negatively related to new firm formation. We look instead at the decision of a person to start a new business or not, and this decision is modelled as 
depending on both personal characteristics and attitudes, and on characteristics of the region.

We contribute to the literature by empirically investigating two issues:

- Does the region matter for the decision to start a new business in Germany ceteris paribus, i.e. after controlling for personal characteristics and attitudes?

- If region matters, what is inside the black box of the regional effect? How do regional characteristics affect the decision to start a new business?

Our econometric study is based on data for 10.000 persons from a recent representative survey of the population in ten German planning regions. We use a version of the probit model that takes care of the regional stratification of the data, and the results of the nonlinear models are carefully interpreted and illustrated.

The rest of the paper is organized as follows: Section 2 develops a theoretical framework for our investigation, section 3 introduces the survey data used and gives some descriptive empirical information on the extent of nascent entrepreneurship activities in German regions, section 4 introduces the empirical model and discusses results from an econometric investigation of the determinants of becoming a nascent entrepreneur and the role played by personal and regional factors, and section 5 concludes.

\section{Theoretical framework}

To discuss the link between personal and regional determinants of entrepreneurial activities consider a utility-maximizing individual that has the choice between paid employment and self-employment. This person will choose the option self-employment if the discounted expected life-time utility from self-employment $\left(\mathrm{DELU}^{\mathrm{S}}\right)$ is higher than that from paid employment $\left(\operatorname{DELU}^{\mathrm{p}}\right)$. The difference $\mathrm{N}_{\mathrm{i}}$ between $\operatorname{DELU}_{\mathrm{i}}^{\mathrm{s}}$ and $\operatorname{DELU}^{\mathrm{p}}{ }_{\mathrm{i}}$,

(1) $\mathrm{N}_{\mathrm{i}}=\operatorname{DELU}_{\mathrm{i}}^{\mathrm{S}}-$ DELU $_{\mathrm{i}}^{\mathrm{p}}$ 
therefore, is crucial for the decision of individual $\mathrm{i}$, and he will choose self-employment if $\mathrm{N}_{\mathrm{i}}$ is positive.

$\operatorname{DELU}^{\mathrm{S}}{ }_{\mathrm{i}}$ and $\operatorname{DELU}^{\mathrm{p}}{ }_{\mathrm{i}}$ are determined by the expected monetary and non-monetary returns from self-employment and paid employment according to the utility function of the person and the individual's discount rate. Higher returns lead to higher values of DELU.

The expected monetary and non-monetary returns from both types of employment depend on variables related to individual $i$, summarized in the vector $x_{i}$, and on variables related to the region $\mathrm{j}$ he lives in, collected in the vector $\mathrm{y}_{\mathrm{j}}$. Given that $\mathrm{N}_{\mathrm{i}}$ depends on $\operatorname{DELU}_{i}^{\mathrm{s}}$ and $\operatorname{DELU}_{i}^{\mathrm{p}}$, and $\operatorname{DELU}_{i}^{\mathrm{s}}$ and $\operatorname{DELU}_{i}^{\mathrm{p}}{ }_{i}$ depend on the monetary and nonmonetary returns, $N_{i}$ can be written as a function of $x_{i}$ and $y_{j}$ :

$$
\text { (2) } \mathrm{N}_{i}=\mathrm{N}_{\mathrm{i}}\left(\mathrm{x}_{\mathrm{i}}, \mathrm{y}_{\mathrm{j}}\right)
$$

Note that we assume here that a person chooses between paid employment and selfemployment in the region he lives in. A rational individual will consider each region $\mathrm{j}(\mathrm{j}=$ $1, \ldots, \mathrm{k})$ and, given his individual characteristics and attitudes, compute $\operatorname{DELU}_{\mathrm{i}}^{\mathrm{s}}$ and $\operatorname{DELU}^{\mathrm{p}}{ }_{\mathrm{i}}$ for all $\mathrm{k}$ regions (taking the costs of moving to a region into account) to choose the region with the maximum among these $2 \mathrm{k}$ values. Given high monetary and non-monetary costs of migration this often (but not alvays) means that a person will stay in the region he lives in.

Individual characteristics and attitudes (elements of $x_{i}$ ), and characteristics of the region (elements of $y_{j}$ ), which have a more positive or less negative impact on DELU ${ }_{i}$ than on DELU ${ }_{i}^{p}$ increase $N_{i}$ (and vice versa). Given that the expected monetary and nonmonetary returns from both types of employment, the utility function, and the discount rate of an individual are unknown to an observer, we cannot observe $\mathrm{N}_{\mathrm{i}}$. Therefore, we cannot test directly whether an individual or regional characteristic - say, age of a person, or population density in a region - has a positive impact on $N_{1}$ or not. If, however, $N_{i}$ is greater than the critical value zero, according to our theoretical framework a person will choose to become an entrepreneur, and the decision to do so or not is observable. In our empirical 
model we will investigate the influence of $x_{i}$ and $y_{j}$ on the probability that a person becomes an entrepreneur by looking at his known decision pro or contra.

The theoretical hypotheses regarding a positive or negative influence of personal characteristics and attitudes, and of characteristics of the region, on this decision are discussed below in section 4 together with a description of the way the elements of $x_{i}$ and $y_{j}$ are measured. Given that details of the specification of the empirical model are (as usual) data driven, we will next turn to a description of the data base used in our study.

\section{The Regional Entrepreneurship Monitor REM Germany 2001 survey}

The data used in this paper are taken from a survey of the German population aged 14 years or older that was conducted using computer assisted telephone interviewing by TNS EMNID, a leading German opinion research institute, in the summer of 2001. This survey is part of the research project Regional Entrepreneurship Monitor REM Germany which focuses on the extent of the difference in entrepreneurial activities between regions in Germany, its determinants, and its consequences for regional development. ${ }^{1}$

In 10 (out of 97) so-called planning regions (or Raumordnungsregionen, see Bundesamt für Bauwesen und Raumordnung, 2001) a random sample of 1.000 people was interviewed, leading to a data set with 10.000 cases. $^{2}$ The questionnaire ${ }^{3}$ asked for sociodemographic characteristics (sex, age, education, marital status, size of household, employment status, income) and a number of items related to entrepreneurial activities (e.g., whether the interviewee is the owner of a firm that is currently actively run by her or him, whether she/he is currently engaged in starting an own business). This data set gives a

\footnotetext{
${ }^{1}$ For further information about the REM project see Bergmann, Japsen and Tamásy (2002). REM is closely related to GEM, the Global Entrepreneurship Monitor, a multi-country study that investigates the same topics at a national level (see Reynolds et al., 2000).

${ }^{2}$ The data will be made available for public scientific use after the completion of the REM project.

${ }^{3}$ An English version of the questionnaire is not yet available; a German version is available from the authors on request.
} 
snapshot of activities and attitudes related to self-employment and new firm formation in the 10 regions in the Summer of 2001. Even if we can not claim that the data are representative for Germany as a whole, the regions were selected in such a way that they mirror the spatial structure with regard to old and new federal states (i.e., West and East Germany), highly industrialized versus more rural regions, center and periphery, etc. With a pinch of salt information relating to the average in the selected regions can be considered to be a valid instrument for information on Germany as a whole.

In the survey the interviewee was asked whether she/he is (alone or with others) actively involved in starting a new business that will (as a whole or in part) belong to her/him, and whether this business did not pay full time wages or salaries for more than three months to anybody (including the interviewee). Those who answered in the affirmative are considered to be nascent entrepreneurs. ${ }^{4}$ The share of this group in the population is 3.7 percent.

Table I reports detailed results for the ten regions. Inter-regional differences in the order of magnitude point to differences in the level of entrepreneurial activity among the regions. The share of nascent entrepreneurs in the population is about twice as high in the regions Köln and München as in the regions Emscher-Lippe and Mittleres Mecklenburg.

[Table I near here]

\section{Personal and regional determinants of entrepreneurial activities: Results from an econometric investigation}

In this section the question what distinguishes nascent entrepreneurs from the rest of population is investigated econometrically. We test for the role played by both personal and regional factors in shaping the probability of becoming a nascent entrepreneur. Section 4.1

\footnotetext{
${ }^{4}$ This definition of a nascent entrepreneur is identical to the definition used in the GEM project mentioned above; see Reynolds et al., 2000, p. 9.
} 
gives an outline of the specification of the empirical model applied, and section 4.2 presents a detailed discussion of the results.

\subsection{An empirical model of determinants of entrepreneurial activities}

According to the theoretical model developed in section 2 above the decision taken by individual $\mathrm{i}$ to become a nascent entrepreneur or not is shaped by his personal characteristics and attitudes (collected in the vector $\mathrm{x}_{\mathrm{p}}$ ), and by characteristics of the region $\mathrm{j}$ he chose to live in (collected in vector $y_{\mathrm{j}}$ ). In our empirical model we regress the observed decision of all persons from the REM survey aged between 18 and 68 on $\mathrm{x}$ and $\mathrm{y}$. Selection of the elements included in $\mathrm{x}$ and $\mathrm{y}$ are, at least in part, data driven. Although we had full control over the design of the questionnaire used in the REM survey, we were unable to collect information on all individual characteristics that are important for the decision under consideration due to budget constraints (that limited the time per interview and the number of items to be included) and the willingness of the interviewees to report information on issues like the amount of personal wealth, or losses in bankruptcies in the past. Effects of variables not included in the empirical model are covered by the error term. Frankly, this might lead to an omitted variables bias - a problem common to many (all?) econometric investigations.

That said, we will now turn to a discussion of the variables measured at the individual and at the regional level that are included in our empirical model. To start with the individual characteristics and attitudes, $x_{i}$ has the following elements:

- Sex (a dummy variable taking the value one if the interviewee is male). Hypothesis: It is a stylized fact that men do have a higher propensity to step into self-employment than women, at least in Germany. Sex is included in our empirical model to control for this difference in behavior between men and women, and we expect a positive sign for the estimated coefficient of the dummy variable.

- Age (measured in years). Hypothesis: On the one hand, age is a proxy variable for personal wealth - the older a person is, the longer is the potential period to accumulate 
wealth. Given that young firms are often constrained by lack of credit because banks usually demand collateral to finance investments, a certain amount of wealth is crucial for starting a new business (see Evans and Jovanovic 1989). This leads to the expectation of a positive sign of the estimated coefficient of the age variable. On the other hand one has to acknowledge that starting a new business often leads to high sunk costs - think of all the effort to set up a business plan, doing market research, dealing with legal and administrative problems, etc. The shorter the expected life span of the new business, the shorter is the period over which these sunk costs can be earned back. To put it differently, setting up a new business with high sunk costs is more attractive at the age of 45 than at the age of 60 , ceteris paribus. This leads to the expectation of a negative sign of the estimated coefficient of the age variable. Given these two opposite influences of age on the propensity to become an entrepreneur it is an empirical question whether one dominates the other, or whether both net out (see Evans and Leighton 1989). Furthermore, it might be the case that the wealth effect dominates in the early years, while the sunk costs effect dominates towards the end of the active life, leading to an inversely u-shaped relationship between age and the probability to become a nascent entrepreneur. To test for this non-linear influence, age is also included in squares.

- Level of education (a dummy variable taking the value one if the interviewee has a higher education, i.e. went to school for at least 12 years, or holds a degree). Hypothesis: This dummy variable is a proxy for the amount of general human capital. Given that success in business demands knowledge in a number of different areas and a sufficient capacity to learn, we expect a positive relationship between higher education and the propensity to step into self-employment.

- Unemployment (a dummy variable taking the value one if the interviewee is unemployed). Hypothesis: Unemployment often acts as a push factor for building a new business. For Germany, this is amplified by the so-called bridging allowances paid by the labor services to help start-ups by (former) unemployed persons. Therefore, a positive coefficient of the dummy variable is expected (on unemployed nascent entrepreneurs in Germany, see Wagner 2002a). 
- Self-employed (a dummy variable taking the value one if the interviewee is selfemployed). Hypothesis: This dummy variable is a proxy for specific human capital related to running your own business, and a positive coefficient is expected (see Evans and Leighton 1989). Note that this variable should not be considered to be of a tautological nature. On the one hand today's self-employed can (and often do) step out of their business and opt for a job as a paid employee. On the other hand an owner of a business might decide to try another chance in a different area of business - in addition to or instead of the business he is running now.

- Failed as a self-employed in the past (a dummy variable taking the value one if an interviewee started - alone or with others - a business in the past that has been closed or given up and not sold to others later). Hypothesis: Like self-employed, this dummy variable is a proxy for specific human capital related to running your own business, and a positive coefficient is expected. Although stigmatization of those who failed once is often seen as a problem (at least, in Germany), taking a second chance is widespread (see Wagner 2002b).

- Personal contact with a young entrepreneur (a dummy variable taking the value one if the interviewee personally knows someone who started a new business during the last two years). Hypothesis: Contacts with young entrepreneurs will reduce costs because they make it easier to get answers to lots of 'how to' type questions related to a start-up. We expect a positive impact of contact with such a 'role model' (see Sternberg 2000, p. 60).

- Fear of failure a reason not to sta rt (a dummy variable taking the value one if the interviewee agreed that fear to fail would prevent him from founding a firm). Hypothesis: If the interviewee answered this question in the affirmative we consider this as an indicator of a high degree of risk aversion, and we expect a negative impact on the probability of becoming a nascent entrepreneur (see Kihlstrom and Laffont 1979).

Descriptive statistics for these variables are given in the upper panel of table II. Among the nascent entrepreneurs we find more males, more people with higher education, more self-employed, more who failed as a self-employed in the past, and with personal contact to a young entrepreneur, and less people who consider fear of failure to be a reason not to start a new business than among the rest of the adult population. Furthermore, 
nascent entrepreneurs are about 3.5 years younger on average. Note that the share of unemployed persons in both groups is the same.

[Table II near here]

Let us now turn to the regional characteristics included in our empirical model that constitute the vector $y_{j}$ :

- Population density (number of residents per square-kilometer in 1998). Hypothesis: Given that the lion's share of new firms is founded in services, a higher population density means more potential customers and higher demand in the region. This has a positive impact on the expected returns to a new business, and according to our theoretical framework we expect this to have a positive influence on the probability to become a nascent entrepreneur.

- Growth rate of population (1990 - 1998; percent). Hypothesis: The higher is the growth rate of population, the higher is the rate of growth of demand for many services, and the better are the chances for newly founded businesses in these areas. Again, this has a positive impact on the expected returns, and, therefore, we expect it to have a positive influence on the probability to become a nascent entrepreneur.

- Average monthly wage and salary in manufacturing (1999; in Deutschmark) Hypothesis: This variable serves as a proxy for the purchasing power in the region and for the demand for goods and services, and we expect a positive impact of higher values on the individual propensity to become a nascent entrepreneur due to positive effects on expected returns. Note that in times of a shrinking manufacturing sector and high unemployment the opportunity to start working in manufacturing for this average salary is not available for most of the interviewees, so this should not be interpreted as the opportunity costs of becoming self-employed for most of the interviewees.

- Average price of building plots (1996 - 1998; DM per square-meter). Hypothesis: The higher the price of land, the higher are the costs for building or renting a flat or shop, and given this negative impact of higher cost on returns we expect a negative impact of 
higher prices of building plots on the individual propensity to become a nascent entrepreneur.

- New firms per 1.000 residents (average 1998 - 2000). Hypothesis: This variable serves as a proxy for the regional entrepreneurial milieu. A high rate of new firm formation points to a climate that is favorable for start-ups in many ways (not measured by the other regional variables included here). Therefore, we expect a positive sign of the estimated coefficient.

Descriptive statistics for these variables 5 are given in the lower panel of table II. Note that on average all regional characteristics included in the empirical model have higher values for the group of nascent entrepreneurs compared to the rest of the adult population.

\subsection{Results of the econometric study}

The ceteris paribus role played by the elements of $x_{i}$ and $y_{j}$ in determining the probability of becoming a nascent entrepreneur is investigated in an econometric model with a dummy endogenous variable taking the value one if a person is a nascent entrepreneur, zero otherwise. To take the survey design described in section 3 above into account, the models were estimated using the survey probit program svyprobit included in Stata 7.0 with the region as the primary sampling unit (psu) to control for clustering; see StataCorp (2001, p. 321ff.). Note that spatial autocorrelation is not an issue in our study because the ten planning regions are scattered all over Germany.

The estimation proceeds in three steps. In step one only personal characteristics and attitudes are included in the empirical model, i.e. the dummy variable for nascent entrepreneurship is regressed on $x_{i}$ only. Results are reported in the column headed 'Model

${ }^{5}$ The source for population density, growth of population, average monthly wage and salary in manufacturing, and average price of building plots is Bundesamt für Bauwesen und Raumordnung (2001); figures for new firms per 1.000 residents are calculated from data reproted in Statistisches Bundesamt (2001). 
$\mathrm{A}^{\prime}$ in Table III. From the prob-values ${ }^{6}$ it follows that according to this model, and in line with our priors, the probability of becoming a nascent entrepreneur is higher for males, people with higher education, unemployed, self-employed, who failed as self-employed in the past, and who have personal contact with a young entrepreneur. It is lower for people with a high degree of risk aversion. All these estimated coefficients are are significantly different from zero at the 6 percent level of error or better. The effect of age is less clear. The sign pattern points to an inversely u-shaped impact of age; the estimated coefficient of the age variable measured in levels is, however, not statistically significant at a conventional level.

[Table III near here]

Model A considers the role of personal attributes and attitudes only. From the descriptive evidence reported in Table I we know that the level of entrepreneurial activity differs considerably between regions. In step two, therefore, we additionally test for the role played by the region in determining whether a person becomes a nascent entrepreneur. Results for an augmented empirical model containing nine dummy variables for the regions (using the Emscher-Lippe region as the standard group) are reported in the clumn headed 'Model B' in Table III. All but one of the estimated coefficients of the region dummies are highly significant statistically, and an adjusted Wald test of the null hypothesis that all these coefficients are zero rejects the null with a p-value of 0.0067. Note that the estimated coefficients for the other variables included and their levels of significance do not differ much between Model A and Model B.

In the third and final step the set of region dummies is replaced by the regional characteristics collected in the vector $\mathrm{y}_{\mathrm{j}}$ Results for this model are reported as 'Model $\mathrm{C}^{\prime}$ in

\footnotetext{
${ }^{6}$ We report prob-values instead of t-values for two reasons: First, the degrees of freedom for the $\mathrm{t}$ in svyprobit are the number of clusters (i.e., regions) minus one, and not the number of observations minus the number of estimated coefficients, and this might cause irritation; second, the prob-values give an immediate and exact impression of the empirical significance level of an estimated coefficient.
} 
Table III. The big picture from the results for the personal characteristics and attitudes is the same as in Model A and B. The characteristics of the regions all have the theoretically expected signs, and all estimated coefficients are statistically significant at the ten percent level or better. According to the findings presented here, higher values of population density and growth, higher earnings in manufacturing, and a higher level of new firm formation intensity have a positive impact on the probability to become a nascent entrepreneur ceteris paribus, i.e. for a given set of personal characteristics and attitudes collected in vector $\mathrm{x}_{\mathrm{i}}$, while higher cost for building plots have a negative impact.

Discussion of results hitherto was limited to the statistical significance of the estimated coefficients and the direction of influence conducted by the variables. Information on the extent of this influence, or on the economic significance, however, is even more important. Evidently, a variable that has no statistically significant impact can be ignored from an economic point of view, but the opposite is not true: A variable that is highly significant statistically might not matter at all economically - if the estimated probability for becoming a nascent entrepreneur diminishes by 0.00001 percent when a person is 68 instead of 18 years old, we can ignore age of a person in any discussion on nascent entrepreneurs irrespective of any high level of statistically significance indicated by the prob-value.

Unfortunately, the estimated coefficients from a probit model (or for any other nonlinear model) can not easily be used for statements about the size of the ceteris paribus effect of a change of the value of an exogenous variable (e.g., an increase in the age of a person by five years) on the value of the endogenous variable (e.g., the probability of becoming a nascent entrepreneur), because the size of this effects depends on both the value of the exogenous variable under consideration and on the values of all other variables in the model (see Long and Freese, 2001, 87ff.).

A way to ease interpretation of the estimation results is to compute the estimated values of the endogenous variable (here: the probability of becoming a nascent entrepreneur) for a person with certain characteristics and attitudes, and then to see how a change in the value of one exogenous variable at a time changes the estimated probability. 
For expository purposes, we define a reference person - call it person 1 - which is male, 40 years old, has higher education, is unemployed, does not consider fear of failure a reason not to start a new firm, has personal contact with a young entrepreneur, is not selfemployed, did fail as a self-employed in the past, and lives in a (fictive) region where all regional variables have values at the sample mean. According to the results reported for model $\mathrm{C}$ in table III the estimated probability for person 1 to become a nascent entrepreneur is 0.217 .

If we consider a person that is identical to person 1 but female (call it person 2), the estimated probability is 0.160 - much lower. The ceteris paribus impact of unemployment is comparable to the effect of sex - a non-unemployed person 3 has an estimated probability of 0.154 . If we look at person 4 who considers fear of failure to be a reason not to start a new firm, we get an estimated probability of 0.142 . The probability for person 5 , who does not have personal contact with a young entrepreneur, is about half the estimate for person 1, i.e. 0.112. For person 6, who is self-employed, we find a much higher value of 0.389 . Person 7, who did not fail as a self-employed in the past, has an estimated probability of 0.106 that is about half as big as person 1 .

Turning to the impact of the regional characteristics we will change the regional variables one at a time from their sample means to their sample maxima. If we do so for the population density, the estimated probability for person 8 increases to 0.268 compared to 0.217 for person 1 . Setting the growth rate of population to its maximum gives a probability of 0.252 for person 9. Living in the region with the highest average monthly wage and salary in manufacturing leads to a value of 0.259 for person 10. Setting the average price of building plots at the sample maximum leads to an estimated probability of 0.142 for person 11. And coming from the region with the highest rate of new firm formation means that person 12 has an estimated probability of 0.256 .

These simulation exercises (and many more not reported here) show that the variables which are statistically significant according to the results reported in table III are important from an economic point of view, too. The decision to become a nascent entrepreneur is 
related to the personal characteristics and attitudes, and to characteristics of the region, in a way that is consistent with our theoretical hypotheses. 


\section{Concluding remarks}

In this paper we look at inter-regional differences in entrepreneurial activity from a perspective that differs from an approach that is widely applied in the literature. Instead of searching for regional characteristics that are positively or negatively related to differences in the amount of new firm formation between regions we focus on the decision of the individual to start a new business or not. This decision depends on personal characteristics and attitudes, and on regional characteristics, that influence the discounted expected lifetime utility from self-employment and paid employment by increasing or decreasing costs and benefits. The results from our empirical model are in line with our theoretical reasoning, and both the personal and the regional determinants turn out to be important. If the se results show up in a similar way in studies based on other data sets from other regions and periods, they might help to shape economic policy measures to foster entrepreneurship in a region.

\section{References}

Audretsch, David B. and Michael Fritsch, 1994, The Geography of Firm Births in Germany. Regional Studies 28, 359-365.

Audretsch, David B. and Michael Fritsch, 2002, Growth Regimes over Time and Space. Regional Studies 36, 113-124.

Bergmann, Heiko, Andrea Japsen and Christine Tamásy, 2002, Regionaler Entrepreneurship Monitor (REM) - Gründungsaktivitäten und Rahmenbedingungen in zehn deutschen Regionen, Universität zu Köln and Universität Lüneburg.

Bundesamt für Bauwesen und Raumordnung, 2001, Aktuelle Daten zur Entwicklung der Städte, Kreise und Gemeinden, Ausgabe 2000, Bonn: Bundesamt für Bauwesen und Raumordnung.

Chell, Elizabeth, Jean M. Haworth and Sally Brearly, 1991, The Entrepreneurial Personality. London: Routledge. 
Evans, David S. and Boyan Jovanovic, 1989, An Estimated Model of Entrepreneurial Choice under Liquidity Constraints. Journal of Political Economy 97, 808-827.

Evans, David S. and Linda S. Leighton, 1989, Some Empirical Aspects of Entrepreneurship. American Economic Review 79, 519-535.

Evans, Laurie Beth and John M. Siegfried, 1994, Empirical Studies of Entry and Exit: A Survey of the Evidence. Review of Industrial Organization 9, 121-156.

Frick, Siegfried et al., 1998, Möglichkeiten der Verbesserung des Umfeldes für Existenzgründer und Selbständige: Wege zu einer neuen Kultur der Selbständigkeit. Essen: RWI.

Fritsch, Michael and Oliver Falck, 2002, New Firm Formation over Industry, Space and Time: A Multi-Level Analysis for Germany. Technical University of Freiberg, mimeo.

Gerlach, Knut and Joachim Wagner, 1994, Regional Differences in Small Firm Entry in Manufacturing Industries. Entrepreneurship and Regional Development 6, 63-80.

Kihlstrom, Richard E. and Jean-Jacques Laffont, 1979, A General Equilibrium Entrepreneurial Theory of Firm Formation Based on Risk Aversion. Journal of Political Economy 87, 719-748.

Lagemann, Bernhard et al., 1999, Kleine und mittlere Unternehmen im sektoralen Strukturwandel. Essen: RWI.

Long, J. Scott and Jeremy Freese, 2001, Regression Models for Categorical Dependent Variables using Stata, College Station, TX: Stata Press.

Reynolds, Paul D., David J. Storey and Paul Westhead, 1994, Cross-national Comparisons of the Variation in New Firm Formation Rates. Regional Studies 28, 443-456.

Reynolds, Paul D. et al., 2000, GEM Global Entrepreneurship Monitor. 2000 Executive Report, Kansas City: Kauffman Center for Entrepreneurial Leadership.

StataCorp, 2001, Stata User's Guide, Release 7, College Station, TX: Stata Corporation.

Statistisches Bundesamt, 2001, Statistik regional, Ausgabe 2001, CD-ROM, Wiesbaden: Destatis.

Steil, Fabian, 1999, Determinanten regionaler Unterschiede in der Gründungsdynamik, Baden-Baden: Nomos. 
Sternberg, Rolf, 2000, Entrepreneurship in Deutschland, Das Gründungsgeschehen im internationalen Vergleich, Länderbericht Deutschland 1999 zum Global Entrepreneurship Monitor, Berlin: edition sigma.

Sternberg, Rolf et al., 2000, Global Entrepreneurship Monitor Länderbericht Deutschland 2000, Köln: Wirtschafts- und Sozialwissenschaftliches Institut, Universität zu Köln.

Sternberg, Rolf et al., 2001, Global Entrepreneurship Monitor Länderbericht Deutschland 2001, Köln: Wirtschafts- und Sozialwissenschaftliches Institut, Universität zu Köln.

Wagner, Joachim, 2002a, The Impact of Personal Characteristics and the Regional Milieu on the Transition from Unemployment to Self-employment: Empirical Evidence for Germany. Jahrbücher für Nationalökonomie und Statistik (forthcoming).

Wagner, Joachim, 2002b, Taking a Second Chance: Entrepreneurial Restarters in Germany. Bonn: Institute for the Study of Labor Discussion Paper Series No. 417. 
Table I: The share of nascent entrepreneurs in selected German regions

$\begin{array}{rr}\text { Region } & \begin{array}{c}\text { Share of nascent } \\ \text { entrepreneurs } \\ \text { the population } \\ \text { (percent) }\end{array} \\ \text { Emscher-Lippe } & \\ \text { Köln } & 2.53 \\ \text { Lüneburg } & 5.87 \\ \text { Main-Rhön } & 4.25 \\ \text { Mittelhessen } & 3.11 \\ \text { München } & 2.63 \\ \text { Mittleres } & 1.95 \\ \text { Schleswig-Holstein Mitte } & 4.63 \\ \text { Stuttgart } & 3.61 \\ \text { Westsachsen/Leipzig } & 2.92 \\ \text { Average } & 2.55 \\ \text { Source: Own calculations based on weighted data from the } & \\ \text { Regional Entrepreneurship Monitor REM Survey 2001 } & \end{array}$




\section{Table II: Descriptive statistics 1}

\begin{tabular}{|c|c|c|c|c|c|c|}
\hline \multirow[b]{2}{*}{ Variable } & \multicolumn{2}{|r|}{ All } & \multicolumn{3}{|c|}{ Nascent entrepreneurs } & \multirow{2}{*}{$\begin{array}{l}\text { Others } \\
\text { Std. Dev. }\end{array}$} \\
\hline & Mean & Std. & Mean & Std. & Mean & \\
\hline Sex (Dummy, $1=$ Male) & 0.45 & 0.50 & 0.64 & 0.48 & 0.44 & 0.50 \\
\hline Age (Years) & 43.23 & 13.49 & 39.63 & 11.28 & 43.35 & 13.55 \\
\hline Age (squared) & 2050.46 & 1189.69 & 1697.10 & 952.33 & 2062.84 & 1195.30 \\
\hline Higher education (Dummy, $1=$ Yes) & 0.38 & 0.49 & 0.53 & 0.50 & 0.38 & 0.48 \\
\hline Unemployed (Dummy, 1 = Yes) & 0.05 & 0.21 & 0.05 & 0.22 & 0.05 & 0.21 \\
\hline Self-employed (Dummy, 1 = Yes) & 0.10 & 0.30 & 0.34 & 0.47 & 0.09 & 0.29 \\
\hline Failed as a self-employed in the past (Dummy, $1=$ Yes) & 0.08 & 0.27 & 0.24 & 0.43 & 0.07 & 0.26 \\
\hline Fear of failure a reason not to start (Dummy, 1 = Yes) & 0.47 & 0.50 & 0.23 & 0.42 & 0.48 & 0.50 \\
\hline Personal contact with a young entrepreneur (Dummy, 1 = Yes) & 0.43 & 0.49 & 0.76 & 0.43 & 0.42 & 0.49 \\
\hline Population density (residents per $\mathrm{km}^{2}$ in 1998) & 405.08 & 337.97 & 432.57 & 334.92 & 404.11 & 338.06 \\
\hline Growth rate of population (1990 - 1998, percent) & 2.27 & 4.50 & 3.10 & 3.92 & 2.24 & 4.51 \\
\hline Average monthly wage and salary in manufacturing (1999; DM) & 5598.73 & 1097.20 & 5830.86 & 1105.09 & 5590.60 & 1096.10 \\
\hline Average price of building plots (1996 - 1998; DM per square-meter) & 217.64 & 194.68 & 226.14 & 189.41 & 217.34 & 194.87 \\
\hline New firms per 1.000 residents (average 1998 - 2000) & 7.85 & 1.50 & 8.08 & 1.60 & 7.84 & 1.50 \\
\hline Number of cases & 7802 & & 26 & & & 7538 \\
\hline
\end{tabular}

Source: Own calculations based on data from the Regional Entrepreneurship Monitor REM Survey 2001 (upper panel); Bundesamt für Bauwesen und Raumordnung (2001) and Statistisches Bundesamt (2001) (lower panel).

1 For a detailed definition of the variables see text. 
I avie in: estumation resums ior uetermmants on vecommg a nascem entepreneur

\begin{tabular}{|c|c|c|c|c|c|c|}
\hline \multirow[b]{2}{*}{ Variable } & \multicolumn{2}{|c|}{ Model A } & \multicolumn{2}{|c|}{ Model B } & \multirow{2}{*}{$\begin{array}{l}\text { Mode } \\
\text { Coeff. }\end{array}$} & \multirow{2}{*}{$\begin{array}{l}\mathrm{C} \\
\mathrm{P}>|t|\end{array}$} \\
\hline & Coeff. & $P>|t|$ & Coeff. & $P>|t|$ & & \\
\hline Sex (Dummy, $1=$ Male) & 0.2154 & 0.011 & 0.2164 & 0.009 & 0.2120 & 0.010 \\
\hline Age (Years) & 0.0303 & 0.126 & 0.0287 & 0.160 & 0.0287 & 0.155 \\
\hline Age (squared) & -0.0005 & 0.052 & -0.0005 & 0.066 & -0.0005 & 0.064 \\
\hline Higher education (Dummy, 1 = Yes) & 0.1227 & 0.060 & 0.1040 & 0.078 & 0.1049 & 0.074 \\
\hline Unemployed (Dummy, 1 = Yes) & 0.1959 & 0.054 & 0.2332 & 0.023 & 0.2380 & 0.021 \\
\hline Self-employed (Dummy, 1 = Yes) & 0.4821 & 0.000 & 0.5052 & 0.000 & 0.5002 & 0.000 \\
\hline Failed as a self-employed in the past (Dummy, $1=$ Yes) & 0.4653 & 0.000 & 0.4626 & 0.000 & 0.4639 & 0.000 \\
\hline Fear of failure a reason not to start (Dummy, $1=$ Yes) & -0.3052 & 0.000 & -0.2845 & 0.000 & -0.2875 & 0.000 \\
\hline Personal contact with a young entrepreneur (Dummy, $1=$ Yes) & 0.4312 & 0.000 & 0.4294 & 0.000 & 0.4315 & 0.000 \\
\hline Region Köln (Dummy, 1 = Yes) & & & 0.2529 & 0.000 & & \\
\hline Region Lüneburg (Dummy, 1 = Yes) & & & 0.1029 & 0.000 & & \\
\hline Region Main-Rhön (Dummy, 1 = Yes) & & & -0.0230 & 0.229 & & \\
\hline Region Mittelhessen (Dummy, 1 = Yes) & & & -0.1015 & 0.000 & & \\
\hline Region Mittleres Mecklenburg (Dummy, 1 = Yes) & & & -0.2646 & 0.000 & & \\
\hline Region München (Dummy, 1 = Yes) & & & 0.1355 & 0.000 & & \\
\hline Region Schleswig-Holstein Mitte (Dummy, 1 = Yes) & & & 0.0651 & 0.000 & & \\
\hline Region Stuttgart (Dummy, 1 = Yes) & & & -0.1282 & 0.000 & & \\
\hline Region Westsachsen/Leipzig (Dummy, 1 = Yes) & & & -0.1074 & 0.000 & & \\
\hline Population density (residents per $\mathrm{km}^{2}$ in 1998) & & & & & $2.33 e-4$ & 0.000 \\
\hline Growth rate of population (1990 - 1998, percent) & & & & & 0.0176 & 0.022 \\
\hline Average monthly wage and salary in manufacturing (1999; DM) & & & & & $6.57 e-5$ & 0.099 \\
\hline Average price of building plots (1996 - 1998; DM per square-meter) & & & & & $-6.22 e-4$ & 0.000 \\
\hline New firms per 1.000 residents (average 1998 - 2000) & & & & & 0.0404 & 0.023 \\
\hline Constant & -1.2678 & 0.000 & -2.6537 & 0.000 & -3.3430 & 0.000 \\
\hline Number of cases & & & & & & \\
\hline
\end{tabular}

1 The models were estimated by Stata 7 using the program svyprobit with the region as a cluster. 


\section{IZA Discussion Papers}

\begin{tabular}{|c|c|c|c|c|}
\hline No. & Author(s) & Title & Area & Date \\
\hline 607 & Y. Zenou & How Do Firms Redline Workers? & 5 & $10 / 02$ \\
\hline 608 & G. Saint-Paul & $\begin{array}{l}\text { Economic Aspects of Human Cloning and } \\
\text { Reprogenetics }\end{array}$ & 3 & $10 / 02$ \\
\hline 609 & G. Saint-Paul & Cognitive Ability and Paternalism & 3 & $10 / 02$ \\
\hline 610 & A. Heitmueller & $\begin{array}{l}\text { Unemployment Benefits, Risk Aversion, and } \\
\text { Migration Incentives }\end{array}$ & 4 & $10 / 02$ \\
\hline 611 & G. Saint-Paul & $\begin{array}{l}\text { Some Thoughts on Macroeconomic Fluctuations } \\
\text { and the Timing of Labor Market Reform }\end{array}$ & 3 & $10 / 02$ \\
\hline 612 & $\begin{array}{l}\text { J. J. Dolado } \\
\text { M. Jansen } \\
\text { J. F. Jimeno }\end{array}$ & $\begin{array}{l}\text { A Matching Model of Crowding-Out and On-the- } \\
\text { Job Search (with an Application to Spain) }\end{array}$ & 2 & $10 / 02$ \\
\hline 613 & $\begin{array}{l}\text { P. Kuhn } \\
\text { M. Skuterud }\end{array}$ & $\begin{array}{l}\text { Internet Job Search and Unemployment } \\
\text { Durations }\end{array}$ & 5 & $10 / 02$ \\
\hline 614 & M. Pannenberg & $\begin{array}{l}\text { Long-Term Effects of Unpaid Overtime: } \\
\text { Evidence for West Germany }\end{array}$ & 1 & $10 / 02$ \\
\hline 615 & W. Koeniger & $\begin{array}{l}\text { The Dynamics of Market Insurance, Insurable } \\
\text { Assets, and Wealth Accumulation }\end{array}$ & 3 & $10 / 02$ \\
\hline 616 & $\begin{array}{l}\text { R. Hujer } \\
\text { U. Blien } \\
\text { M. Caliendo } \\
\text { C. Zeiss }\end{array}$ & $\begin{array}{l}\text { Macroeconometric Evaluation of Active Labour } \\
\text { Market Policies in Germany - A Dynamic Panel } \\
\text { Approach Using Regional Data }\end{array}$ & 6 & $10 / 02$ \\
\hline 617 & $\begin{array}{l}\text { L. Magee } \\
\text { M. R. Veall }\end{array}$ & $\begin{array}{l}\text { Allocating Awards Across Noncomparable } \\
\text { Categories }\end{array}$ & 1 & $10 / 02$ \\
\hline 618 & $\begin{array}{l}\text { A. L. Booth } \\
\text { M. Francesconi } \\
\text { G. Zoega }\end{array}$ & $\begin{array}{l}\text { Oligopsony, Institutions and the Efficiency of } \\
\text { General Training }\end{array}$ & 6 & $10 / 02$ \\
\hline 619 & $\begin{array}{l}\text { H. Antecol } \\
\text { D. A. Cobb-Clark }\end{array}$ & $\begin{array}{l}\text { The Changing Nature of Employment-Related } \\
\text { Sexual Harassment: Evidence from the U.S. } \\
\text { Federal Government (1978-1994) }\end{array}$ & 5 & $10 / 02$ \\
\hline 620 & D. A. Cobb-Clark & $\begin{array}{l}\text { Public Policy and the Labor Market Adjustment } \\
\text { of New Immigrants to Australia }\end{array}$ & 1 & $10 / 02$ \\
\hline 621 & G. Saint-Paul & On Market Forces and Human Evolution & 5 & $11 / 02$ \\
\hline 622 & $\begin{array}{l}\text { J. Hassler } \\
\text { J. V. Rodriguez Mora }\end{array}$ & Should UI Benefits Really Fall Over Time? & 3 & $11 / 02$ \\
\hline 623 & $\begin{array}{l}\text { A. R. Cardoso } \\
\text { P. Ferreira }\end{array}$ & $\begin{array}{l}\text { The Dynamics of Job Creation and Destruction } \\
\text { for University Graduates: Why a Rising } \\
\text { Unemployment Rate Can Be Misleading }\end{array}$ & 1 & $11 / 02$ \\
\hline 624 & $\begin{array}{l}\text { J. Wagner } \\
\text { R. Sternberg }\end{array}$ & $\begin{array}{l}\text { Personal and Regional Determinants of } \\
\text { Entrepreneurial Activities: Empirical Evidence } \\
\text { from the REM Germany }\end{array}$ & 1 & $11 / 02$ \\
\hline
\end{tabular}

An updated list of IZA Discussion Papers is available on the center's homepage www.iza.org. 